\title{
Sewage, green algal mats anchored by lugworms, and the effects on Turbellaria and small Polychaeta*
}

\author{
Karsten Reise \\ Biologische Anstalt Helgoland (Litoralstation); \\ D-2282 List/Sylt, Federal Republic of Germany \\ and \\ II. Zoologisches Institut, Universität Göttingen; \\ D-3400 Göttingen, Federal Republic of Germany
}

\begin{abstract}
On sandy tidal flats at the Island of Sylt (North Sea) ephemeral mats of green algae covered wide areas in the vicinity of sewage outflows. Algae became anchored in the feeding funnels of lugworms (Arenicola marina) and thus were able to resist displacement by tidal currents. Below the algal mats anoxic conditions extend to the sediment surface. After about one month a rough sea removed all algae. Polychaetes endured this short-term environmental deterioration, while the more sensitive Turbellaria decreased in abundance and species richness. Diatom-feeders were affected most, predators to a medium extent, and bacteria-feeders the least affected. Rare and very abundant species were more affected than moderately abundant ones. None of the turbellarian species increased in abundance and none colonized the algal mats above the sediment. In a semicontrolled experiment with daily hand-removal of drift algae from a $100-\mathrm{m}^{2}$ plot within an extensive field of algal mats, this cleaned "island" served as a refuge to Turbellaria escaping from their algal covered habitat. Here abundance doubled relative to initial conditions and was 5-times higher than below algal mats.
\end{abstract}

\section{INTRODUCTION}

Excessive growth of green seaweeds in response to sewage effluents is becoming an increasingly common phenomenon in sheltered marine bays (Perkins \& Abbott, 1972; Tubbs, 1977; Wharfe, 1977; Michaelis, 1978; Nicholls et al, 1981; and references therein). Ammonium and nitrate are crucial while phosphate is not (Harlin \& ThorneMiller, 1981). Along intertidal sedimentary shores, wide areas of former open mudlands are covered by continuous mats of filamentous and membranous algae (Chlorophyceae: Enteromorpha spp., Ulva spp.), 10 to $15 \mathrm{~cm}$ in thickness. The underlying sediment becomes anoxic, reducing and toxic hydrogen sulfide accumulates (Wharfe, 1977). The macrofauna of these sediments suffers losses but some snails colonize the algal mats. Wading birds forage elsewhere but brent geese and wigeons accept these green algae as food (Nicholls et al., 1981; Tubbs, 1977).

Because algal mats covering intertidal sediments are likely to expand further as eutrophication of the sea increases, a close examination of their effects on benthic fauna

* This work was supported by a grant from the Deutsche Forschungsgemeinschaft ( $\operatorname{Re} 425 / 3$ ). 
is advisable. In this study, the response of meiobenthic Turbellaria and of small Polychaeta to ephemeral green algal cover on sandy flats is documented. Turbellaria are very rich in species on sandy tidal flats and comprise bacteria-feeders, diatom-feeders and predators. They are often overlooked by routine sampling because many disintegrate or form unrecognizable cell-masses in preserved sediment samples. Sorting of living animals is required. Species identification, however, is relatively easy and the sensitive response of Turbellaria to short-term environmental degradation makes this group well suited for investigations into pollution effects on a taxon rich in species. While the larger polychąetes are able to survive under the algal mats, Turbellaria suffer severe losses and/or escape when conditions get worse. Trophic groups, rare and abundant species respond differently.

\section{AREA AND METHODS}

Two study sites developing algal cover during summer were selected in Königshafen, a shallow tidal bay at the Island of Sylt (North Sea). Hydrography, sediments and macrofauna of the area have been described by Wohlenberg (1937), macroalgae by Nienburg (1927) and Kornmann (1952). Sandy flats are relatively coarse grained (median $456 \mu \mathrm{m}, \mathrm{phi}=1.14$, sorting coefficient 1.5 ). Organic content is ca $0.4 \%$ (dry weight). Salinity remains close to 31 . Annual mean temperature is ca $10^{\circ} \mathrm{C}$, summer average is 15.1, winter average 4.5 . Tidal range is $1.7 \mathrm{~m}$.

Site 1 in the inner part of Königshafen is at mid tide level, Site 2 in the outer part of Königshafen close to low tide level. Both are adjacent to minor domestic sewage effluents. In summer, the outflow close to Site 1 is fed by about 1000 people and sewage is almost untreated. Close to Site 2 the outflow is fed by about 7000 people and sewage is mechanically treated (low particle load but high concentrations of ammonium and phosphate; see Otte, 1979).

At Site 1 sampling was done after a month of coherent algal cover (17 July 1981). Sediment cores of $2 \mathrm{~cm}^{2} / 0-5 \mathrm{~cm}$ were taken directly underneath algal mats $(\mathrm{n}=5$ ), from small open interspaces temporarily uncovered $(n=5)$, and from a bare region $150 \mathrm{~m}$ apart from the other sample positions and about $20 \mathrm{~m}$ outside the algal field $(n=5)$. In addition, pieces of algal mat were cut out for investigation. Turbellaria and small Polychaeta were sorted while alive without sieving the sediment cores. To sample larger polychaetes, cores of $10 \mathrm{~cm}^{2} / 0-5 \mathrm{~cm}$ were washed through a $0.5-\mathrm{mm}$ sieve.

At Site 2, two adjacent plots, $10 \times 10 \mathrm{~m}$, were marked. Algal strands were first noticed on 23 July 1981, and from July 28 on they were removed from one of the plots by hand each day until August 26. Drift algae were collected and dumped about $50 \mathrm{~m}$ away. This kept the experimental plot reasonably free from algal cover while the adjacent control was covered by a coherent mat with only small interspaces from August 5 onward. Sampling was done at the beginning of experiment to document the initial conditions (July 28), and thereafter every 10 days on the cleaned plot. On August 26 the algal area also was sampled. Ten cores of $2 \mathrm{~cm}^{2} / 0-2 \mathrm{~cm}$ were taken each time, and pieces of algal mats were cut out.

Non-parametric tests are applied to the sets of samples (Wilcoxon rank sum U-test; Kruskal-Wallis multiple comparison $\mathrm{H}$-test). $\mathrm{P}>0.05$ is regarded as not significant (ns). Diversity is expressed as $D=\left(\Sigma p_{i}^{2}\right)^{-1}$ and $H^{\prime}=-\Sigma p_{i} \ln p_{i}$, where $p_{i}$ is the relative 
proportion of species $\mathrm{i}$ from the total of individuals. Evenness was measured with a modified Hill's ratio proposed by Alatalo (1981), written as $(\mathrm{D}-1) /(\operatorname{expH}-1)$, where $\exp H^{\prime}$ is the antilogarithm of $H^{\prime}$. Compared to Pielou's evenness this measure is less affected by species richness.

Species identity in Turbellaria is usually confirmed by inspection of the complex reproductive organs. Juveniles cannot always be assigned to a species with certainty. In the present study, this is the case in the genera Proxenetes ( $3 \mathrm{spp}$.) and Promesostoma (6 spp.). Juveniles comprised $72 \%$ and $37 \%$, respectively. In calculating diversity indices and plotting species versus abundance class, these juveniles were assigned in proportion to the species being present as adults. Gut analyses and feeding observations have been carried out on Turbellaria at Site 2 since June 1980 (see Reise, 1983), and categories given in Table 5 are based on that study.

\section{RESULTS}

\section{Green algal mats on sandy tidal flats}

Germlings of Enteromorpha spp., attached to sand grains, increase in length in early summer, get branchy, and finally become plaited to tresses by tidal currents and wave action. These strands of green algae drift back and forth with the tides and finally become deposited in sheltered areas, or storms pile them up along the shoreline. However, since 1979, algal strands have remained on sandy flats. Explosive growth in June/July led to the formation of thick algal mats, covering wide areas in the intertidal zone at the Island of Sylt. Usually they stayed there until the end of August when storms removed them. Enteromorpha spp. are the first to take root, then other algae join the mats (i.e. Ulva spp., Cladophora spp., Chaetomorpha spp., Porphyra spp.).

On sandy flats, strands of green algae may find a hold on tube-caps of polychaetes (i.e. Lanice conchilega Pallas) and mollusc shells. However, in the present case, algae became primarily anchored by the sedentary polychaete Arenicola marina (L.). This deposit feeder populates the sandy flats with a mean density of $40 \mathrm{~m}^{-2}$ (Reise, 1981). Together with surface sediment, strands of algae slide down the feeding funnels and head shafts and thus become "rooted" in 12 to $20 \mathrm{~cm}$ depth (Fig. 1). This certainly is unintended by the lugworms because they shift their head shafts into new positions once clogged by algae.

When algae have grown into coherent mats, $A$. marina fixes them to the sediment with its backwards oriented activity too. During low tide, casts are piled on top of the algal mats, thus burying them at these spots. Primarily it is the lugworm population which prevents the green algal mats from drifting to more sheltered flats. This conclusion is derived from a lugworm exclusion experiment started in June 1979 at Site 1 . At three $4-\mathrm{m}^{2}$ plots, gauze of $1 \mathrm{~mm}$ mesh was inserted horizontally into the ground approximately $10 \mathrm{~cm}$ deep. The gauze blocked the way to the surface and thus forced the worms to move out at the sites. In July 1981, the entire sediment at Site 1 was covered by thick algal mats except the three plots where algae found no anchorage because $A$. marina was excluded.

In 1981 when this investigation was carried out, coherent mats were apparent at Site 1 from the middle of June to the end of August. At Site 2, algal strands were first noticed 

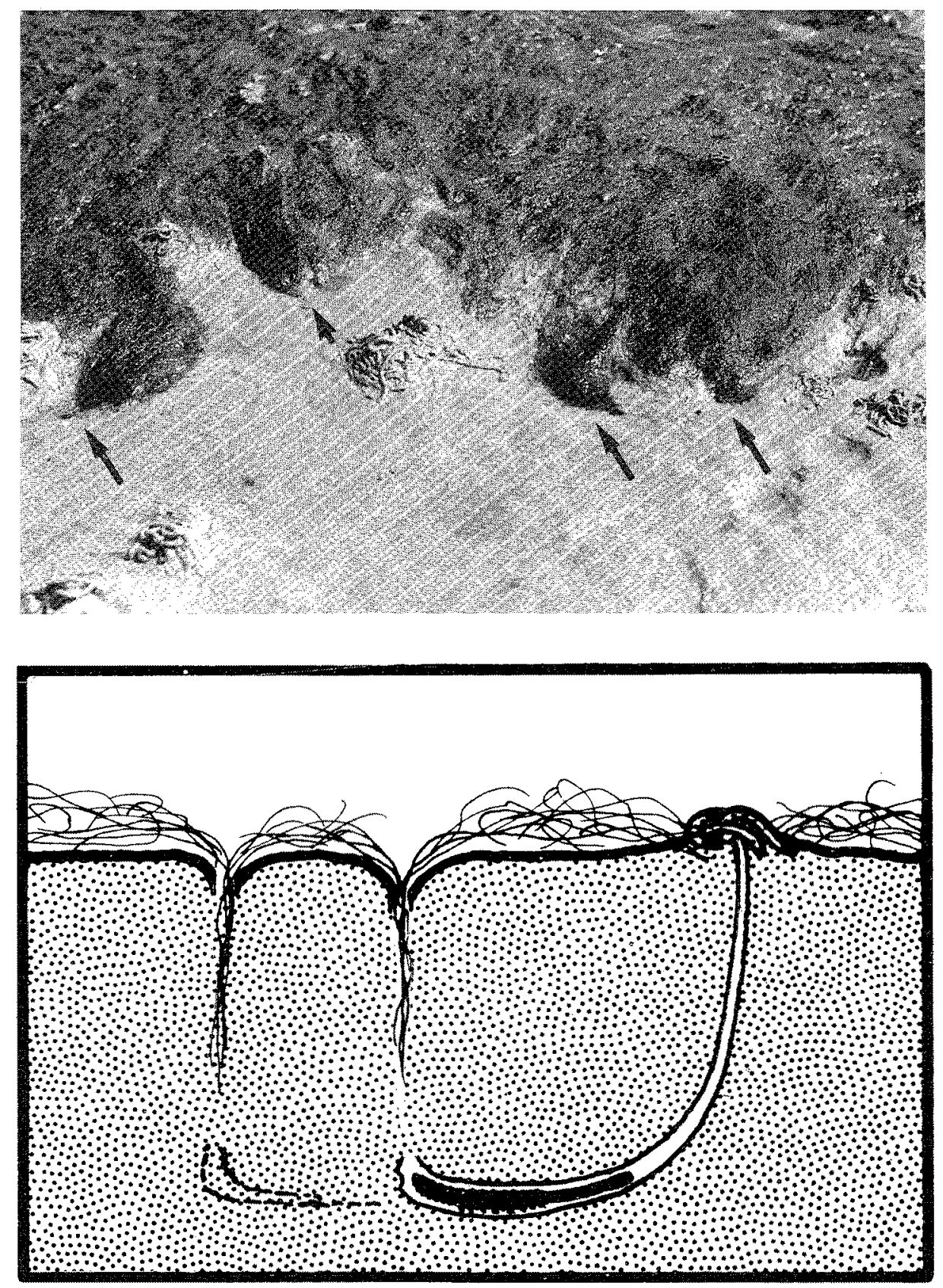

Fig. 1. Strands of Enteromorpha spp. slide down the head shafts of Arenicola marina and become anchored in the sediment (see arrows above). On the right are three open funnels. Coiled casts are spread over the surface. The schematic cross-section below shows a lugworm burrow with an abandoned head shaft to its left (clogged with algae) and an algal mat above 
on July 23. Already 12 days later, coherent mats covered about $50 \%$ of the surface. Within a few days, coverage was almost total, extending over about 2 ha. At the end of August, storms removed all algal cover.

\section{Polychaeta with and without algal cover}

One month of algal cover at Site 1 did not significantly affect the composition of the polychaete assemblage (Table 1). This statement is in part compelled by the high variation within sets of samples. More extensive sampling of small polychaetes might have revealed a significant increase in juvenile Capitella capitata. In the experiment at Site 2 no significant differences between treatments (U-test) or over the period of 30 days on the cleaned area (H-test) were observed (Table 2). Diversity and evenness are relatively high under algal cover because Pygospio elegans loses its dominance. However, the decrease in abundance of this species is not significant ( $U$-test, $P=0.25$ ).

\section{Turbellaria with and without algal cover}

Green algal mats have adverse effects on all benthic Turbellaria. At Site 1, samples were taken one month after the onset of algal cover (Table 3). Small, temporarily open patches provide no rescue. Abundance and species richness are significantly higher on the bare flat (U-test, $\mathrm{P}<0.001$ ). Diversity is lower in the algal field, evenness higher. This is because the dominant species on the bare flat (Cheliplanilla caudata, Cicerina brevicirrus, Promesostoma rostratum) lose their dominance below algal cover. No Turbellaria were found within the floating algal mats. Even on the bare flat, abundance was

Table 1. Polychaeta within and outside an algal covered field, a sandy flat at Site 1, Königshafen, July 19, 1981. "Small Polychaeta" are those obtained by direct sorting of $2 \mathrm{~cm}^{2} / 0-5 \mathrm{~cm}$ samples $(\mathrm{n}=5)$. "Larger Polychaeta" are those retained in a $0.5 \mathrm{~mm}$ mesh when sieving cores of $10 \mathrm{~cm}^{2} /$

$0-5 \mathrm{~cm}(\mathrm{n}=10)$. Open interspaces between algal mats were not sampled for the latter group

\begin{tabular}{|c|c|c|c|}
\hline Polychaeta & $\begin{array}{l}\text { Below } \\
\text { algal } \\
\text { mats }\end{array}$ & $\begin{array}{c}\text { Interspaces } \\
\text { between } \\
\text { algal mats }\end{array}$ & $\begin{array}{c}\text { Bare flat } \\
20 \mathrm{~m} \\
\text { outside }\end{array}$ \\
\hline & \multicolumn{3}{|c|}{ individuals $\cdot 10 \mathrm{~cm}^{-2}$} \\
\hline All small Polychaeta & 27 & 23 & 23 \\
\hline Scoloplos armiger (Müller) & 19 & 10 & 19 \\
\hline Microphthalmus sczelkowii Mec. & 1 & 10 & 1 \\
\hline Capitella capitata (Fabr.) & 7 & 3 & 1 \\
\hline \multirow[t]{2}{*}{ Pygospio elegans Clap. } & 0 & 0 & 2 \\
\hline & \multicolumn{3}{|c|}{ individuals $\cdot 100 \mathrm{~cm}^{-2}$} \\
\hline All larger Polychaeta & 19 & & 18 \\
\hline Scoloplos armiger (Müller) & 6 & & 8 \\
\hline Capitella capitata (Fabr.) & 8 & & 6 \\
\hline Heteromastus filiformis (Clap.) & 1 & & 1 \\
\hline Pygospio elegans Clap. & 4 & & 2 \\
\hline Spio filicornis (Müller) & 0 & & 1 \\
\hline
\end{tabular}


Table 2. Small Polychaeta during the algae-removal experiment in Königshafen, July to August 1981. Numbers refer to 10 samples of $2 \mathrm{~cm}^{2}=20 \mathrm{~cm}^{2}$

\begin{tabular}{|c|c|c|c|c|c|}
\hline \multirow{2}{*}{ Polychaeta } & \multirow{2}{*}{$\begin{array}{c}\text { Initial } \\
\text { conditions } \\
\text { July } \\
28\end{array}$} & \multicolumn{3}{|c|}{ Cleaned area } & \multirow{2}{*}{$\begin{array}{c}\text { Algal } \\
\text { mats } \\
\text { Aug. } \\
26\end{array}$} \\
\hline & & $\underset{7}{\text { Aug. }}$ & $\begin{array}{c}\text { Aug. } \\
16\end{array}$ & $\begin{array}{c}\text { Aug. } \\
26\end{array}$ & \\
\hline All Polychaeta & 124 & 113 & 87 & 105 & 79 \\
\hline Scoloplos armiger (Müller) & 19 & 4 & 5 & 1 & 5 \\
\hline Capitella capitata (Fabr.) & & & 1 & 1 & 3 \\
\hline Heteromastus filiformis (Clap.) & 12 & 7 & 3 & 3 & 2 \\
\hline Arenicola marina - juv. & & & 2 & 6 & 1 \\
\hline Eteone longa (Fabr.) & & & & 1 & \\
\hline Anaitides mucosa (Oersted) & & & & & 1 \\
\hline Microphthalmus sczelkowii Mec. & 25 & 12 & 15 & 23 & 27 \\
\hline Microphthalmus aberrans (W \& B) & 1 & 1 & & 1 & \\
\hline Nephtys hombergi Savigny & 1 & 1 & & 1 & \\
\hline Polydora ligni Webster & 1 & & 2 & 6 & 2 \\
\hline Pygospio elegans (Clap.) & 51 & 68 & 43 & 43 & 22 \\
\hline Spio filicornis (Müller) & 14 & 11 & 14 & 18 & 14 \\
\hline Tharyx marioni (Saint-Joseph) & 1 & 9 & 2 & 1 & 2 \\
\hline Species richness & 8 & 8 & 9 & 12 & 10 \\
\hline Diversity D & 3.91 & 2.53 & 3.27 & 3.95 & 4.29 \\
\hline Diversity $\mathrm{H}^{\prime}$ & 1.56 & 1.35 & 1.53 & 1.71 & 1.72 \\
\hline Evenness & 0.77 & 0.54 & 0.63 & 0.66 & 0.72 \\
\hline
\end{tabular}

Table 3. Turbellaria within and outside an algal covered field, sandy flat at Site 1, Königshafen, July 19,1981 . Five samples of $2 \mathrm{~cm}^{2} / 0-5 \mathrm{~cm}$ were taken for each category

\begin{tabular}{|llcc|}
\hline Turbellaria $\cdot 10 \mathrm{~cm}^{-2}$ & $\begin{array}{c}\text { Below } \\
\text { algal } \\
\text { mats }\end{array}$ & $\begin{array}{c}\text { Interspaces } \\
\text { between } \\
\text { algal mats }\end{array}$ & $\begin{array}{c}\text { Bare flat } \\
20 \mathrm{~m} \\
\text { outside }\end{array}$ \\
\hline All Turbellaria & 8 & 6 & 35 \\
Species richness & 6 & 5 & 16 \\
Diversity D & 4.57 & 4.50 & 8.90 \\
Diversity H' & 1.67 & 1.56 & 2.48 \\
Evenness & 0.83 & 0.93 & 0.73 \\
\hline
\end{tabular}

low compared to that measured years before algal mats started covering extensive areas. Abundance $\left(10 \mathrm{~cm}^{-2}\right)$ before green algae came was: 107 in July 1977, 226 in July 1978. With algae it was 52 in June 1979, 49 in July 1980, 6 to 35 in July 1981.

At Site 2, algal cover was not observed previously. Keeping an area of $100 \mathrm{~m}^{2}$ clean of macroalgae by daily hand-removal was favourable to Turbellaria. After 30 days of algal removal, the ambient flat was then covered by thick algal mats for 21 days, turbellarian abundance was 5-times higher and species density 3-times higher on the cleaned flat, compared to that with algal mats (Table 4). The difference was most pronounced in diatom-feeding Turbellaria (9.8-fold), less in predators (4.2-fold) and bacteria-feeders (2.8-fold). Diatom-feeders also increased significantly in their propor- 
Table 4. Turbellarian assemblage during algae-removal experiment in Königshafen, July to August 1981. Numbers refer to 10 samples of $2 \mathrm{~cm}^{2}=20 \mathrm{~cm}^{2}$. Tests are performed with Turbellaria in individual samples. Probabilities (P) of Kruskal \& Wallis'H-test refer to homogeneity of abundances from July 28 to August 26 on the cleaned area. Probabilities of Wilcoxon's U-test refer to differences between cleaned area and algal control on August 26. No tests are performed on indices of diversity and evenness. $\mathrm{ns}=\mathrm{P}>0.05$

\begin{tabular}{|c|c|c|c|c|c|c|c|}
\hline \multirow[b]{2}{*}{ Turbellaria } & \multirow{2}{*}{$\begin{array}{c}\text { H-test } \\
\mathrm{P}\end{array}$} & \multirow{2}{*}{$\begin{array}{c}\text { Initial } \\
\text { conditions } \\
\text { July } \\
28\end{array}$} & \multicolumn{3}{|c|}{ Cleaned area } & \multirow{2}{*}{$\begin{array}{l}\text { Algal } \\
\text { mats } \\
\text { Aug. } \\
26\end{array}$} & \multirow{2}{*}{$\begin{array}{c}\text { U-test } \\
\quad P\end{array}$} \\
\hline & & & $\begin{array}{c}\text { Aug. } \\
7\end{array}$ & $\begin{array}{c}\text { Aug. } \\
16\end{array}$ & $\begin{array}{c}\text { Aug. } \\
26\end{array}$ & & \\
\hline All Turbellaria & $<0.001$ & 140 & 166 & 170 & 286 & 54 & $<0.001$ \\
\hline Bacteria-feeders & ns & 22 & 10 & 15 & 31 & 11 & $<0.05$ \\
\hline Diatom-feeders & $<0.001$ & 64 & 82 & 84 & 128 & 13 & $<0.001$ \\
\hline Predators & $<0.01$ & 54 & 74 & 70 & 125 & 30 & $<0.001$ \\
\hline \multicolumn{8}{|l|}{ Dominant taxa $(>3.4 \%)$} \\
\hline Bresslauilla relicta & $<0.01$ & 4 & 0 & 8 & 14 & 5 & $\mathrm{~ns}$ \\
\hline Postmecynostomum pictum & ns & 7 & 14 & 7 & 11 & 1 & $<0.05$ \\
\hline Provortex tubiferus & ns & 20 & 14 & 10 & 12 & 2 & $<0.01$ \\
\hline Macrostomum pusillum & $<0.01$ & 22 & 38 & 36 & 53 & 3 & $<0.001$ \\
\hline Pogaina suecica & $<0.001$ & 11 & 5 & 21 & 46 & 5 & $<0.001$ \\
\hline Archilopsis unipunctata & ns & 13 & 13 & 16 & 27 & 12 & ns \\
\hline Promesostoma (6 supp.) & 0.01 & 20 & 40 & 29 & 61 & 11 & $<0.001$ \\
\hline Species richness & $<0.05$ & 24 & 24 & 26 & 36 & 19 & $<0.001$ \\
\hline Diversity D & & 12.63 & 10.57 & 11.02 & 11.01 & 10.13 & \\
\hline Diversity $\mathrm{H}^{\prime}$ & & 2.80 & 2.72 & 2.82 & 2.85 & 2.61 & \\
\hline Evenness & & 0.75 & 0.67 & 0.64 & 0.62 & 0.72 & \\
\hline
\end{tabular}

tion relative to the other trophic groups (U-test, $P<0.05$ ). The species particularly affected by algal cover were the three diatom-feeding Macrostomum pusillum, Pogaina suecica and Postmecynostomum pictum. On the cleaned area, the relative proportion of M. pusillum within the turbellarian assemblage increased significantly (U-test, $\mathrm{P}<0.05)$. This is also indicated for $P$. suecica $(\mathrm{P}=0.06)$, while Archilopsis unipunctata is on a slightly increasing trend $(\mathrm{P}=0.09)$. The difference in species richness is conspicuous, but diversity is only slightly higher on the cleaned flat because of a low evenness component.

Based on the complete species abundance data (Table 5), graphs of species versus abundance class (geometric intervals) are presented for (1) Turbellaria at the onset of algal growth (start of experiment), (2) Turbellaria below algal cover one month later, and (3) Turbellaria on the cleaned plot (Fig. 2). Initially, the turbellarian assemblage was characterized by a high evenness where species with a moderate number of individuals dominated. Under algal cover most species have only few individuals and none are very abundant. Chance of survival under algal cover is calculated per geometric abundance class (initial conditions are set to $100 \%$ ). Individuals of initially rare species as well as those of initially very abundant species have a low chance of survival, while individuals of moderately abundant species have a more than $50 \%$ chance (Fig. 2).

On the experimental plot free of algae there are many rare species and four which 
Table 5. Abundance (individuals $\cdot 20 \mathrm{~cm}^{-2}$ ) of turbellarian species before algal growth commenced (start of experiment), one month later below algal cover, and on the experimental plot free of green algae. $\mathrm{B}=$ bacteria-feeder, $\mathrm{D}=$ diatom-feeder, $\mathrm{P}=$ predator

\begin{tabular}{|c|c|c|c|c|}
\hline $\begin{array}{l}\text { Trophic } \\
\text { group }\end{array}$ & Species & $\begin{array}{c}\text { Initial } \\
\text { conditions } \\
\text { July } 28\end{array}$ & $\begin{array}{c}\text { Algal } \\
\text { mats } \\
\text { Aug. } 26\end{array}$ & $\begin{array}{l}\text { Bare flat } \\
\text { Aug. } 26\end{array}$ \\
\hline $\mathrm{D}$ & Macrostomum pusillum Ax & 22 & 3 & 53 \\
\hline D & Provortex tubiferus Luther & 20 & 2 & 12 \\
\hline $\mathbf{P}$ & Archilopsis unipunctata Fabr. & 13 & 12 & 27 \\
\hline $\mathrm{D}$ & Pogaina suecica Luther & 11 & 5 & 46 \\
\hline $\mathrm{B}$ & Neoschizorhynchus parvorostro Ax \& $\mathrm{H}$. & 9 & 3 & 7 \\
\hline $\mathrm{P}$ & Proxenetes quinquespinosus $\mathrm{Ax}$ & 8 & 1 & 3 \\
\hline $\mathrm{D}$ & Postmecynostomum pictum Dörjes & 7 & 1 & 11 \\
\hline $\mathrm{P}$ & Promesostoma marmoratum Schultze & 6 & 0 & 10 \\
\hline $\mathrm{B}$ & Philomecynostomum lapillum Dörjes & 5 & 2 & 6 \\
\hline $\mathbf{P}$ & Cheliplanilla caudata Meixner & 5 & 1 & 1 \\
\hline $\mathrm{B}$ & Bresslauilla relicta Reisinger & 4 & 5 & 14 \\
\hline $\mathrm{P}$ & Promesostoma rostratum Ax & 4 & 6 & 28 \\
\hline $\mathbf{P}$ & Promesostoma gracilis $\mathrm{Ax}$ & 4 & 4 & 11 \\
\hline $\mathbf{P}$ & Promesostoma karlingi Ehlers & 3 & 0 & 2 \\
\hline $\mathbf{P}$ & Paromalostomum dubium de Beauchamp & 3 & 1 & 5 \\
\hline $\mathrm{P}$ & Polystyliphora filum $\mathrm{Ax}$ & 3 & 0 & 2 \\
\hline $\mathrm{D}$ & Pseudaphanostoma pelophilum Dörjes & 3 & 0 & 1 \\
\hline $\mathrm{B}$ & Balgetia semicirculifera Karling & 2 & 0 & 0 \\
\hline $\mathrm{B}$ & Paedomecynostomum bruneum Dörjes & 1 & 1 & 0 \\
\hline B & Antroposthia unipora Faubel & 1 & 0 & 4 \\
\hline D & Archimonotresis limophila Meixner & 1 & 0 & 1 \\
\hline $\mathrm{P}$ & Cicerina brevicirrus Meixner & 1 & 2 & 7 \\
\hline $\mathrm{P}$ & Placorhynchus octaculeatus Karling & 1 & 0 & 3 \\
\hline $\mathrm{D}$ & Pseudostomum quadrioculatum Leuck & 0 & 2 & 2 \\
\hline $\mathrm{P}$ & Brinkmanniella macrostomoides Luther & 0 & 1 & 1 \\
\hline $\mathrm{P}$ & Coelogynopora tenuis Meixner & 0 & 1 & 0 \\
\hline $\mathbf{P}$ & Proxenetes ampullatus $\mathrm{Ax}$ & 0 & 0 & 3 \\
\hline $\mathrm{P}$ & Proxenetes quadrispinosus Den Hartog & 0 & 0 & 3 \\
\hline $\mathbf{P}$ & Promesostoma meixneri Ax & 0 & 0 & 3 \\
\hline $\mathbf{P}$ & Zonorhynchus seminascatus Karling & 0 & 0 & 3 \\
\hline D & Aphanostoma album Dörjes & 0 & 0 & 2 \\
\hline $\mathbf{P}$ & Carenscoilia spec. 1 & 0 & 0 & 2 \\
\hline $\mathrm{P}$ & Promonotus schultzei Meixner & 0 & 0 & 1 \\
\hline $\mathbf{P}$ & Halammovortex macropharynx Meixner & 0 & 0 & 1 \\
\hline $\mathrm{P}$ & Typhlopolycystis spec. 1 & 0 & 0 & 1 \\
\hline \multirow[t]{3}{*}{$\mathbf{P}$} & Schizorhynchoides spirostylus Boaden & 0 & 0 & 1 \\
\hline & Psammorhynchus tubulipenis Meixner & 0 & 0 & 1 \\
\hline & Rhinepera remanei Meixner & 0 & 0 & 1 \\
\hline
\end{tabular}

are extremely abundant (Fig. 2 below). As the number of species and overall abundance is considerably higher than one month earlier (Table 4), the experimental plot probably received Turbellaria from outside. This conclusion is substantiated by the following details: (1) Abundance increased particularly between August 16 and August 26. In this interval strong winds (6 to 8 on Beaufort scale) prevailed for 7 days. The rough sea facilitated dispersal. (2) Promesostoma rostratum occurred with three mature and 


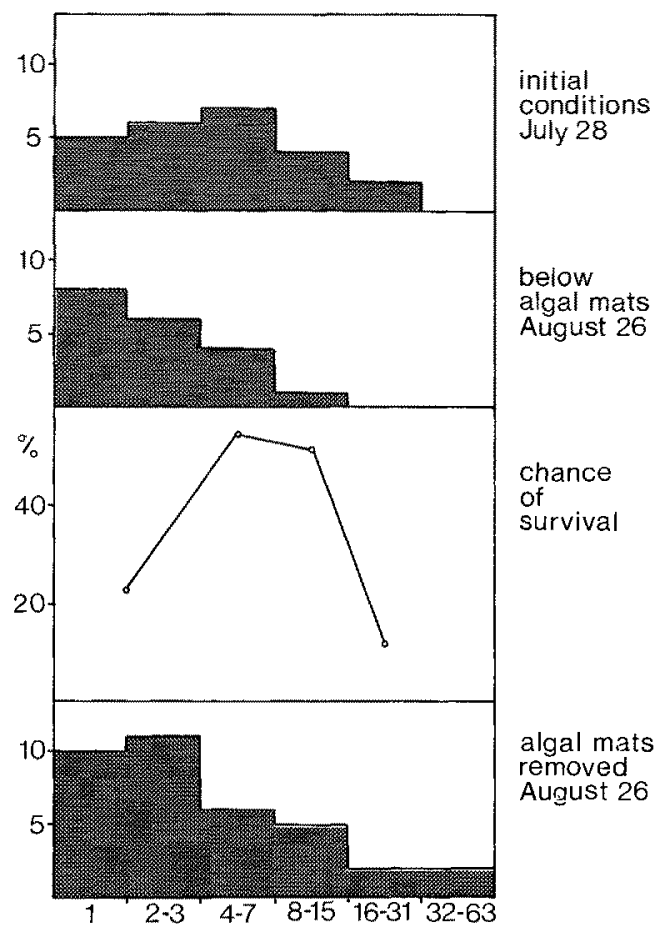

Fig. 2. Number of species (abscissa) versus geometric abundance class (ordinate) of Turbellaria at the beginning and end of experiment (see Table 5), and chance of survival for individuals subject to algal cover. Number of species present initially are set to $100 \%$ (first two classes are taken together to obtain a comparative number of individuals) and the fraction of species present below the algae are assumed to be survivors

2 juvenile individuals in the samples from August 16. Only 10 days later, there were 20 mature $P$. rostratum. (3) Species richness increased from 26 to 36 in the same interval. These observations and other data presented in Table 4 indicate a substantial immigration of Turbellaria from the algal covered flat into the insular experimental plot free of algae. This immigration caused a decrease in evenness because abundant species further improved their dominance. Rare species did not become more common but other rare species arrived. While diatom-feeders and predators doubled their numbers since the initiation of experiment, there was no significant increase in bacteria-feeders on the cleaned plot (Table 4).

\section{DISCUSSION}

\section{Green algal mats}

The macroalgae and seagrasses of Königshafen were investigated in 1924 to 1926 by Nienburg (1927). He provided a map of the vegetation. Regions with growth of Enteromorpha spp. between April and July were located close to the high tide line, just 
above the Zostera noltii belt (his $Z$. nana). Dense growth of Chaetomorpha linum was observed in two muddy bights. All in all, only small patches were covered $(<1 \mathrm{ha})$. Later, Wohlenberg (1937) and Kornmann (1952) also mention these green algae but report no excessive growth either. The present green algal mats occur from the Zostera noltii belt on downwards, where no green algal growth was observed earlier. According to Nienburg's map, Site 1 was vegetated by a small variety of Zostera marina (his $Z$. angustifolia), and Site 2 was without any macrophytes.

I have no direct evidence that the present algal mats are caused by sewage effluents. However, this is very likely because (1) they were absent from the flats in earlier times when no or little sewage entered the bay, (2) they occur in July-August when sewage load is more than doubled because of the tourist season, (3) their proximity to the two outflows is a pattern which has consistently been observed elsewhere in the Wadden Sea, and has been repeatedly reported from other regions (see reviews in Harlin \& Thorne-Miller, 1981; Nicholls et al., 1981).

Sewage may not be the only agent, and favourable weather, particularly a calm sea, is another prerequisite (Perkins \& Abbott, 1972). Under the hydrographic conditions in Königshafen, abundance of Arenicola marina is important, as it keeps the algal mats on the sandy flats in spite of the strong tidal currents. Without the anchorage provided by the lugworms' feeding funnels, the green algal mats would be confined to more sheltered sites or get washed out of the bay. A. marina is abundant on almost all sandy tidal flats along European coasts, and outside Europe other lugworm species may play a similar role. Thus, the unintended "rooting" of green algae by lugworms might happen elsewhere when enhanced eutrophication causes explosive growth of these algae.

\section{Polychaeta below algal mats}

One month or less of algal cover caused no measurable losses in polychaetes at both sites, and no species increased significantly. Nicholls et al. (1981) who investigated muddy flats covered by green algal mats from May to December each year, found striking effects on polychaetes. All species were less abundant below algal mats except two, Capitella capitata and Scolelepis fuliginosa, which became extremely numerous. As many of these species occur also at Site 1 and 2, the difference is likely to lie in the duration of algal cover ( 1 month versus 8 months). Compared to the smaller Turbellaria, polychaetes show more stamina when their habitat is subjected to adverse conditions.

\section{Turbellaria below algal mats}

Turbellaria are abundant and diverse on sandy flats. A long-term decline in abundance at Site 1 coincides with the year when algal mats were observed for the first time. However, the unusually severe winter of 1979 with its ice cover lasting 67 days at Site 1, where normally there is none or one lasting less than a week, may be another cause. At Site 2, algal cover was observed in 1981 for the first time. Here average abundance and species richness of Turbellaria is generally high: $111 \cdot 10 \mathrm{~cm}^{-2}$ and 83 species from June 1980 to June 1981 (Reise, 1983). Samples during the experiment in July/August 1981 gave an average of $87 \cdot 10 \mathrm{~cm}^{-2}$ and a total of 42 species.

These Turbellaria are very sensitive to environmental deterioration caused by an 
ephemeral algal cover. All declined; no species took advantage of the altered habitat. With respect to the sediment this is not surprising as anoxic conditions developed below algal cover, and there seem to be no Turbellaria favouring purely anoxic sediments (Reise \& Ax, 1979). On the surface, diatom growth was probably inhibited by shading (see Sullivan, 1976). This may have caused food shortage to diatom-feeders.

On the green algae themselves, epiphytic diatoms were observed. Snails, Hydrobia ulvae, grazed on these and not on the green algae. Some ciliates and copepods were also present. Phytal Turbellaria, however, remained absent. Probably the duration of algal mats on the sand flats was too short for colonization.

Diatom-feeding Turbellaria declined dramatically when covered by green algae, while predominantly bacteria-feeding species were less affected. This may reflect the effects of green algae on the respective food resources. On the other hand, diatomfeeders are surface-dwelling species and as such more sensitive to anaerobic conditions than the deeper dwelling bacteria-feeders. Predators show an intermediate response.

Compared to the initial conditions one month earlier, algal cover caused high losses in rare and very abundant species. The moderately abundant species did better. Therefore diversity and evenness indicate little change. This pattern of survival suggests that the initially most abundant species may be regarded as "specialists", unable to cope with a change in habitat. Moderately abundant species seem to include most "generalists", better prepared to survive altered conditions.

\section{A refuge from algal mats}

The semi-controlled field experiment conducted at Site 2 revealed that Turbellaria were able to escape from their deteriorating habitat. The $100-\mathrm{m}^{2}$ plot kept clean of green algae was located right in the middle of the algal field. What was intended to be a control area to the algal mats eventually turned out to be a refuge for Turbellaria in need of a new habitat. The cleaned area was well within reach, and even more so when a rough sea facilitated dispersal. Compared to initial conditions, the refuge is characterized by an increased number of rare species and some which became extremely abundant. The number of moderately abundant species remained about the same. The corresponding graph of species versus geometric abundance class resembles that of macrobenthos under polluted conditions, except that rare species are more significant (see Gray \& Pearson, 1982).

The fact that the control served as a rescue area fouled my experiment which had been designed to quantify the effects of algal cover on Turbellaria. However, the importance of area size is highlighted, and should be considered when effects of algal cover are evaluated. If spatial refuges are nearby, considerable numbers of Turbellaria can survive the ephemeral habitat change by escape and later may recolonize. Furthermore, the observed escape response may serve as a warning, not to take dwindling abundances in benthos simply as mortality unless the dead individuals are actually found.

\section{CONCLUSIONS}

Excessive growth of green algae (Chlorophyceae) on the tidal flats of the Wadden Sea during summer is attributed to eutrophication by adjacent sewage effluents. Mats of 
these algae cover wide areas on sheltered flats, and on sandy flats algae become anchored in the feeding funnels of the abundant polychaete Arenicola marina. Algal covered sediments turn anoxic and affect the infauna. Storms are able to dislocate the algal mats, and sandy flats are usually covered for no more than one month. Such shortterm cover is endured by polychaetes but the smaller Turbellaria suffer severe losses.

In this species-rich taxon, abundance, species richness and diversity decreased while evenness increased, compared to the bare sand flat areas. Particularly affected were diatom-feeders; moderately abundant species survived better than the rare and very abundant ones. None of the species was able to take advantage of the habitat alteration. Preventing algal growth on an experimental plot within an extensive field of algal mats demonstrated the capability of some Turbellaria to move out and take advantage of nearby rescue areas. This is the first study using the sensitivity of Turbellaria to document effects of pollution. It is concluded that sewage-induced algal mats severely reduce abundance and diversity of meiobenthic Turbellaria.

Acknowledgements. I thank the staff of the Biologische Anstalt Helgoland for kindly providing laboratory facilities and technical support. Colleagues at the Litoralstation List were very helpful with stimulating discussions.

\section{LITERATURE CITED}

Alatalo, R. V., 1981. Problems in the measurement of evenness in ecology. - Oikos 37, 199-204.

Gray, J. S. \& Pearson, T. H., 1982. Objective selection of sensitive species indicative of pollutioninduced change in benthic communities. I. Comparative methodology. - Mar. Ecol. Prog. Ser. 9, 111-119.

Harlin, M. M. \& Thorne-Miller, B., 1981. Nutrient enrichment of seagrass beds in a Rhode Island coastal lagoon. - Mar. Biol. 65, 221-229.

Kornmann, P., 1952. Die Algenvegetation von List auf Sylt. - Helgoländer wiss. Meeresunters. 4, 55-61.

Michaelis, H., 1978. Recent biological phenomena in the German Waddensea. - Rapp. P.-v. Réun. Cons, int. Explor. Mer. 172, 276-277.

Nicholls, D. J., Tubbs, C. R. \& Haynes, F. N., 1981. The effect of green algal mats on intertidal macrobenthic communities and their predators. - Kieler Meeresforsch. (Sonderh.) 5, 511-520.

Nienburg, W., 1927. Zur Okologie der Flora des Wattenmeeres. I. Teil. Der Königshafen bei List auf Sylt. - Wiss. Meeresunters. (Abt. Kiel) 20, 146-196.

Otte, G., 1979. Untersuchungen über die Auswirkung kommunaler Abwässer auf das benthische Ókosystem mariner Watten. - Helgoländer wiss. Meeresunters. 32, 73-148.

Perkins, E. J. \& Abbott, O. J., 1972. Nutrient enrichment and sand flat fauna. - Mar, Pollut. Bull. 3, $70-72$.

Reise, K., 1981. Okologische Experimente zur Dynamik und Vielfalt der Bodenfauna in den Nordseewatten. - Verh. dt. zool. Ges. 1981, 1-15.

Reise, K., 1983. Turbellaria of a marine sand flat: An ecological study. - Mikrofauna mar. 1 (in press).

Reise, K. \& Ax, P., 1979. A meiofaunal "thiobios" limited to the anaerobic sulfide system of marine sand does not exist. - Mar. Biol. 54, 225-237.

Sullivan, M. J., 1976. Long-term effects of manipulating light intensity and nutrient enrichment on the structure of a salt marsh diatom community. - J. Phycol. 12, 205-210.

Tubbs, C. R., 1977. Muddy foreshores. In: The coastline. Ed. by R. S. K. Barnes. Wiley, London, 83-92.

Wharfe, J. R., 1977. An ecological survey of the benthic invertebrate macrofauna of the lower Medway estuary, Kent. - J, Anim. Ecol. 46, 93-110.

Wohlenberg, E., 1937. Die Wattenmeer-Lebensgemeinschaften im Königshafen von Sylt. - Helgoländer wiss. Meeresunters. 1, 1-92. 